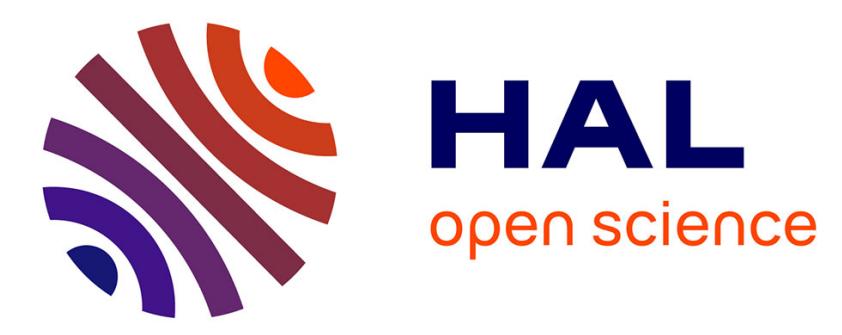

\title{
Protecting the transportation sector from the negative impacts of climate change
}

Georgia Lykou, George Stergiopoulos, Antonios Papachrysanthou, Dimitris

Gritzalis

\section{- To cite this version:}

Georgia Lykou, George Stergiopoulos, Antonios Papachrysanthou, Dimitris Gritzalis. Protecting the transportation sector from the negative impacts of climate change. 11th International Conference on Critical Infrastructure Protection (ICCIP), Mar 2017, Arlington, VA, United States. pp.3-21, 10.1007/978-3-319-70395-4_1. hal-01819137

\section{HAL Id: hal-01819137 \\ https://hal.inria.fr/hal-01819137}

Submitted on 20 Jun 2018

HAL is a multi-disciplinary open access archive for the deposit and dissemination of scientific research documents, whether they are published or not. The documents may come from teaching and research institutions in France or abroad, or from public or private research centers.
L'archive ouverte pluridisciplinaire HAL, est destinée au dépôt et à la diffusion de documents scientifiques de niveau recherche, publiés ou non, émanant des établissements d'enseignement et de recherche français ou étrangers, des laboratoires publics ou privés.

\section{(c)(1)}

Distributed under a Creative Commons Attribution| 4.0 International License 


\title{
Chapter 1
}

\section{PROTECTING THE TRANSPORTATION SECTOR FROM THE NEGATIVE IMPACTS OF CLIMATE CHANGE}

Georgia Lykou, George Stergiopoulos, Antonios Papachrysanthou and Dimitris Gritzalis

\begin{abstract}
Observed and projected climate changes, such as temperature increase, sea-level rise and increases in the frequency and intensity of extreme weather events, are posing challenges to critical infrastructure operations, especially in the transportation sector, which is a pillar of economy and society. Like the other critical infrastructure sectors, the transportation sector comprises complex systems with responsibilities distributed across many stakeholders. The challenges to implementing integrated climate change adaptation approaches in the transportation sector require appropriate governance and coordinated action.

Adaptation to climate change demands resilient and sustainable infrastructures. However, despite the importance of the transportation sector and the huge challenges posed by climate change, adaptation to climate change as a means to reduce risk in the sector is relatively low. Adaptation actions require climate vulnerability analyses and impact knowledge that would help ensure that adaptation options are properly identified, evaluated and monitored. This research attempts to identify and analyze global adaptation initiatives in order to classify adaptation options while also focusing on emerging adaptation challenges and opportunities in the transportation sector. This research should assist the various stakeholders in improving the effectiveness and future sustainability of transportation while stimulating actions for adapting to climate change.
\end{abstract}

Keywords: Climate change, transportation sector, adaptation options

\section{Introduction}

Modeling studies indicate that global average temperatures will increase more than two degrees Celsius over the next century [3]. The United Nations 
Intergovernmental Panel on Climate Change (IPCC) [1] has provided evidence that these changes will have significant implications on extreme weather events, economic development and stability, population and environmental health. Climate change concerns with regard to the critical infrastructure focus on climate variations and extreme weather events that will increase in magnitude, frequency and/or duration [3]. Critical infrastructure assets are typically designed to withstand weather-related stressors common in specific localities, but shifts in climate patterns increase the ranges and types of potential risks. Most infrastructure assets that are being constructed today are expected to last for decades or even centuries [13]. Investing in infrastructures that are not designed to cope with climate change will almost certainly result in significant increases in future costs and amplify the potential for unplanned outages and failures.

Transportation is a critical infrastructure that supports the smooth functioning of society and the prosperity and viability of local, regional and national economies [4]. It facilitates access to services that are vital to commerce and the quality of human life. Gradual climate changes such as increases in temperature, sea level and rainfall along with the projected growth in the frequency and intensity of extreme weather events will seriously challenge the transportation sector. While mitigation efforts are of great importance, critical infrastructures such as transportation must be adapted to reduce the emission of anthropogenic gases and their contributions to climate change.

This research examines a number of climate change adaptation approaches, strategies and action plans with the goal of understanding adaptation measures that are applicable to the transportation sector. Also, it provides a detailed classification and analysis of each adaptation measure according to established methodologies. It focuses on the impacts on the transportation sector and examines national and sectoral adaptation plans for best practices and efficient adaptation options.

\section{Transportation Sector}

Transportation involves the movement of people and goods from one location to another [6]. The transportation sector comprises: (i) transportation infrastructure - fixed installations such as roads, railroads, bridges, canals, pipelines and terminals (e.g., airports, railroad stations, bus stations and seaports); (ii) vehicles - cars, buses, trucks, railroad cars and locomotives, ships, aircraft, drones, etc.; and (iii) operations - people, institutions, laws, policies and information systems that transform infrastructure and vehicles into working transportation networks [2]. Modes of transportation include road, rail, pipelines, water, air and space.

Transportation activities are the result of bringing together diverse resources. Service providers put together these resources to provide different modes of transportation that collectively offer a variety of transportation services to customers. Regulators at various administrative levels provide the basic rules to enable transportation operations to run smoothly, efficiently and with minimal 
impacts [6]. Finally, the numerous users of the transportation modes make their choices and shape the demand for transportation.

Disruptions to transportation systems can cause large economic and human losses. For this reason, the transportation sector is characterized as a critical infrastructure - an important pillar of economy and society [9]. Since most stakeholders may only have a partial perspective of the transportation systems they manage or use [4], without a national protection strategy, the stakeholders would react autonomously and in an uncoordinated manner to address the challenges imposed by climate change. Given the broad impacts of climate variations and the strong interconnectivity within the transportation sector, such a fragmented approach would lead to great inefficiencies and negative impacts on the sustainability and resilience of the transportation infrastructure.

\subsection{Climate Change Impacts on Transportation}

Rising temperatures and extended periods of heatwaves increase rail buckling, road pavement deterioration and thermal discomfort for vehicular passengers [9]. Weather extremes cause floods and landslides that result in short-term delays and interruptions in multiple transportation modes as well as long-term interruptions and detours when land-side infrastructures are damaged or destroyed. Sea-level rise threatens harbors and other transportation infrastructure assets and services in coastal areas. Air transport is impacted by changing wind patterns, floods and other extreme weather events. Additionally, climate impacts can trigger changes to society (e.g., different tourist destinations) and the economy (e.g., reduced agricultural production). Tables 1 and 2 present the climatic events and risks of climate change for various transportation modes based on a literature analysis $[4,9,16]$.

The effects of malfunctions, disturbances and broken transportation links may stretch far beyond the originally-affected areas [17]. The transportation system has a transboundary character and is highly interconnected within and across the various transportation modes; hence, disturbances in one portion of a transportation network could have domino effects in other parts of the network [13]. The effects typically involve service disruptions that prevent the movement of passengers and goods. The interdependencies could result in losses that are many times higher than the direct costs to the transportation sector itself $[4,12]$.

The European Joint Research Centre [10] has presented a comprehensive quantitative assessment of the impacts of current and future climate extremes on critical infrastructures in Europe. The dynamics of climate hazards were analyzed throughout the 21st century using physical models and adaptation tools. The assessment reveals that damage in Europe as a result of climate extremes could triple by the 2020s and amount to more than ten times the current damage of 3.4 billion euros per year by 2100 . According to the study, heat waves will cause the most damage, primarily to roads and railroad tracks. These transportation modes will also suffer losses from coastal flooding, which will increase drastically over time. Inland waterway transport will be impacted 
Table 1. Climate change events and risks on transportation (Part 1).

\begin{tabular}{lll}
\hline Type & Climatic Events & \multicolumn{1}{c}{ Risks } \\
\hline & Summer heat & $\begin{array}{l}\text { Rail buckling, material fatigue, increased insta- } \\
\text { bility of embankments, overheating of equipment }\end{array}$ \\
increase in wildfires and infrastructure damage
\end{tabular}

by droughts while sea-level rise and increased storm surges will significantly increase the damage to ports. These projections create an urgent need to develop and implement an adaptation approach with a long-term, systemic perspective.

\section{Approaches for Climate Change Adaptation}

Adaptation involves actions that respond to current and future climate change impacts and vulnerabilities [8]. This involves protecting against the negative impacts of climate change as well as building resilience and leveraging any benefits it may provide. This section discusses adaptation assessment, adaptation options and classification, and global adaptation initiatives. 
Table 2. Climate change events and risks on transportation (Part 2).

\begin{tabular}{|c|c|c|}
\hline Туре & Climatic Events & Risks \\
\hline \multirow{4}{*}{ 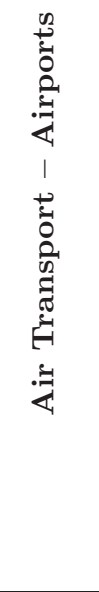 } & Summer heat & $\begin{array}{l}\text { Greater need for ground cooling, degradation of } \\
\text { runways and foundations, reduced engine effi- } \\
\text { ciency due to higher air density at high alti- } \\
\text { tudes, decreased airport lift and increased runway } \\
\text { lengths }\end{array}$ \\
\hline & $\begin{array}{l}\text { Extreme precipi- } \\
\text { tation }\end{array}$ & $\begin{array}{l}\text { Flood damage to runways and other infrastruc- } \\
\text { tures, water run-off exceeds capacity of drainage } \\
\text { systems }\end{array}$ \\
\hline & Sea-level rise & $\begin{array}{l}\text { Flooding of runways, outbuildings and access } \\
\text { roads }\end{array}$ \\
\hline & In general: & $\begin{array}{l}\text { Interruption and disruption of services and ground } \\
\text { access, delays and passenger loss of confidence, } \\
\text { periodic airport closures and higher maintenance } \\
\text { costs }\end{array}$ \\
\hline \multirow{5}{*}{ 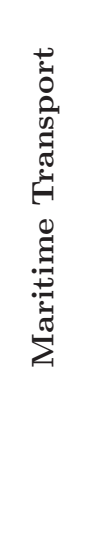 } & $\begin{array}{l}\text { Changes in sea } \\
\text { conditions }\end{array}$ & $\begin{array}{l}\text { More severe storms and extreme waves, restric- } \\
\text { tions on loading capacities and routes, navigation } \\
\text { problems }\end{array}$ \\
\hline & Sea-level changes & $\begin{array}{l}\text { Navigation affected by changes in sedimentation } \\
\text { rates, inland shipping disruptions }\end{array}$ \\
\hline & $\begin{array}{l}\text { Fewer days below } \\
\text { freezing }\end{array}$ & $\begin{array}{l}\text { Reduced problems due to ice accumulation on ves- } \\
\text { sels, decks, riggings and docks, occurrence of dan- } \\
\text { gerous ice fog }\end{array}$ \\
\hline & Reduced sea ice & $\begin{array}{l}\text { Improved access, longer shipping seasons, new } \\
\text { routes }\end{array}$ \\
\hline & In general: & $\begin{array}{l}\text { Disruption of just-in-time delivery of goods, in- } \\
\text { land shipping limitations, welfare losses }\end{array}$ \\
\hline $\begin{array}{l}n \\
\vdots \\
0 \\
0\end{array}$ & $\begin{array}{l}\text { Extreme storms, } \\
\text { sea-level rise, } \\
\text { floods, landslides }\end{array}$ & $\begin{array}{l}\text { Devastation of infrastructure, increased } \\
\text { maintenance and restoration costs, flow } \\
\text { bottlenecks and interruptions, welfare losses }\end{array}$ \\
\hline
\end{tabular}

\subsection{Adaptation Assessment}

Adaptation assessment is the practice of identifying options to adjust to climate change and evaluating them based on criteria such as availability, benefits, costs, effectiveness, efficiency and feasibility [3]. Two main types of analyses are used to assess potential adaptation: (i) identification of adaptation options; and (ii) evaluation of adaptation options [14]:

- Identification of Adaptation Options: Adaptation options are intended to address climate vulnerabilities and build resilience by reduc- 
ing the negative impacts to acceptable levels. Adaptation options may also leverage positive opportunities that arise from climate change [19]. Adaptation options range from actions that build adaptive capacity (e.g., sharing information and creating supportive institutional frameworks) to concrete adaptation measures (e.g., technical solutions, warning systems and insurance mechanisms). Limits to adaptation options are imposed by the specific times when the actions can be implemented and the geographical locations where the actions may be executed. Additionally, there exist inherent limits and uncertainty about the extent to which the actions can enhance the adaptive capacity and protect regions, economic sectors and communities. It is also challenging to decide on the most appropriate protection levels to implement based on the knowledge of current and projected climate change impacts and damage costs.

- Evaluation of Adaptation Options: After a set of adaptation options has been identified, the next step is to evaluate the options in order to guide decisions regarding their selection and implementation. World Resources Institute and World Bank guidance documents [21] list several criteria for evaluating the suitability of an adaptation option in contributing to an objective: (i) cost analysis, including total costs and cost effectiveness; (ii) environmental implications; (iii) secondary or cross-sectoral impacts, externalities or co-benefits; (iv) social implications, including implications for sensitive groups; (v) short-, medium- and long-term efficacy; (vi) effectiveness at reducing the impacts of extreme events; (vii) effectiveness under different climate scenarios; (viii) limiting factors for implementation and sustainability (e.g., resource constraints); (ix) consultation with a broad set of stakeholders; (x) provision for reviewing options based on changing assessments of risk; and (xi) transparency in the process and justification of option selection.

\subsection{Classification of Adaptation Options}

The European Environment Agency [8] classifies adaptation actions into three broad categories:

- Green Actions: These actions involve ecosystem-based approaches that leverage nature-provided services to achieve cost effective and possibly more feasible adaptation solutions. Examples include green earthworks to combat landslides, renewable energy sources and low energy demand infrastructures.

- Soft Actions: These actions involve managerial, legal and policy approaches that alter human behavior and governance styles such as new policies and procedures, land-use controls, information dissemination and economic incentives that reduce or prevent disaster vulnerability. Examples include legislation, standards and best practices, and public information campaigns. 
- Gray Actions: These actions involve various technological and engineering solutions for infrastructure, corresponding to physical interventions, construction measures and using engineering services to enable infrastructures to withstand extreme events. Examples include coastal and river flood defenses, early warning systems, redundant equipment and networks.

Green and soft actions specifically focus on decreasing the sensitivity and increasing the adaptive capacity of human and natural systems to foster resilience; these actions are often less resource intensive and provide multiple benefits. Gray actions involve innovative technological solutions that typically cost more and require more research, experience and training to be implemented.

Adaptation has an extremely important role in reducing the economic costs of climate change. While adaptation has a cost, it significantly reduces the financial consequences of inaction and, in many cases, provides benefits that dramatically outweigh the costs [9]. Since it is important to enable cost-effective and proportionate adaptation to climate change, options that can achieve adaptation while minimizing the associated risks and uncertainties are especially appropriate.

In addressing adaptation risk and uncertainty, the United Kingdom Climate Impacts Programme (UKCIP) [19], categorizes options as no regrets, low regrets, win-win and adaptive/flexible management options that target incremental adaptation:

- No Regret Adaptation Options: These adaptation actions are worthwhile regardless of the extent of future climate change. They include justified and cost-effective measures under current climate conditions that are further justified when their introduction is consistent with addressing risks associated with projected climate changes.

- Low Regret Adaptation Options: These adaptation actions have relatively low costs and their benefits, although primarily realized under projected climate changes, may be relatively large.

- Win-Win Adaptation Options: These adaptation actions minimize climate risks and exploit potential opportunities; additionally, they support mitigation and other social and environmental objectives. Some of these actions may have been introduced for reasons other than addressing climate risks, but they also deliver the desired adaptation benefits.

- Adaptive Management Options: These adaptation actions are incremental and flexible, and do not effect large-scale adaptation. The actions are based on assessments of the current environment, but are designed for incremental change (including changing the direction) as knowledge, experience and technology evolve.

In contrast, maladaptation options hinder or reduce climate change adaptation and must be avoided to the extent possible: 
- Maladaptation Options: These maladaptation actions: (i) do not increase resilience and adaptive capacity or do not reduce vulnerabilities; (ii) are not sustainable from an environmental, economic or social perspective (e.g., over-exploitation of water resources); or (iii) conflict with other long-term policy objectives.

Maladaptation can be prevented by considering the climatic and socioeconomic elements that constitute vulnerabilities to climate change.

\subsection{Global Adaptation Initiatives}

A variety of adaptation initiatives are underway around the world. The U.S. Department of Homeland Security has developed a climate change adaptation roadmap and climate action plan that align with the President's climate action

plan, preparing the United States for the impacts of climate change [2]. As of 2016, fifteen states have published climate adaptation plans.

The European strategy for adaptation to climate change sets out a framework and mechanisms to prepare for current and future impacts [7]. The strategy encourages and supports actions by European Union member states and creates a basis for informed decision-making on adaptation in the years to come. The majority of the member states have adopted national adaptation plans and strategies that outline their implemented and planned actions to facilitate the adaptation of transportation and other sectors to climate change.

The Australian Government has developed the ACT Climate Change Adaptation Strategy that coordinates efforts focused on adapting to climate change. This strategy identifies key adaptation policies to enable communities to become more resilient by communicating the risks and impacts of climate change and incorporating climate change risk considerations and adaptation actions in government policies.

\section{Adaptation in the Transportation Sector}

This section, which constitutes the core of the chapter, identifies and analyzes climate change adaptation actions in the transportation sector. The actions are drawn from national adaptation strategies and relevant publications such as U.S. Government reports, European Union directives and publiclyavailable adaptation action plans $[2,5,9,15,20]$.

This section also introduces and categorizes the adaptation options for the transportation sector using the classification categories discussed above. Seven types of options are analyzed, each dealing with a different aspect of adaptation: (i) effective governance; (ii) infrastructure planning; (iii) redundancies within and between transportation modes; (iv) operational contingencies; (v) early warning systems; (vi) building adaptive capacity; and (vii) collaboration. In the following, each adaptation option is presented along with a table that summarizes the classification of the adaptation options. The presentation and classification of adaptation actions are intended to stimulate further research and discussion by transportation sector stakeholders. 


\subsection{Adaptation to Climate Change}

The transportation sector routinely deals with extreme events that cause disruptions, whether they stem from natural hazards or human-initiated events such as accidents and power outages, and has developed resilience strategies. Therefore, the adaptation of transportation systems to climate change requires a wide perspective that embeds adaptation in broader transition strategies [9] instead of leaving it to be implemented by individual stakeholders such as infrastructure owners/operators or regulatory authorities.

Transportation is specifically addressed in most of the national strategies and plans studied in this research. The national strategies and plans primarily focus on the transportation infrastructure and aspects of transportation services, such as the development of alternative routes and means of transportation, traffic management, reviews of technical conditions of vehicles and vehicular operations, and support to transportation infrastructure owners/operators in developing their adaptation assessments and actions. The literature (see, e.g., [20]) reveals that stakeholders such as railroad companies [15], airports and port authorities, and air traffic control operators [5] are well aware of the potential climate change impacts and the need to adapt, and have started taking action. The prospects of significant reconstruction costs, lengthy recovery processes and severe disruptions have influenced transportation infrastructure owners/operators to undertake comprehensive assessments of their assets.

\subsection{Effective Governance for Adaptation}

The primary role of government is to enable adaptation actions at the local and regional levels by creating an appropriate framework [6,21]. This includes effective institutions, knowledge, supportive policy, laws and regulations, and funding. As such, transportation should also be a part of national adaptation strategies and action plans.

Since stakeholders acting at the local, regional or company levels implement actions such as climate-proofing infrastructure and operations, it is vital that authorities create synergies and engage all the stakeholders in the transportation sector. Enhancing legislation with national standards for earth and public works and requiring climate risk assessments as a prerequisite for new asset construction can ensure the integrity and future protection of the transportation infrastructure.

Public funding for new or existing infrastructure reinforcement should incorporate adaptation assessments to ensure infrastructure sustainability. Table 3 presents the effective governance actions categorized according to adaptation option type. Note that most of actions proposed are soft measures, except for funding issues. This is not surprising because the roles of government are mostly managerial and policy setting, which create the appropriate framework for executing adaptation actions at the local, regional and national levels. 
Table 3. Effective governance actions proposed in adaptation plans.

\begin{tabular}{|c|c|c|c|c|c|c|c|}
\hline Adaptation Action & ש્d & ڤ̆ & 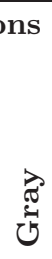 & $\begin{array}{l}\mathrm{Ri} \\
\text { n } \\
0 \\
\vdots \\
0 \\
0 \\
\simeq \\
0 \\
\text { Z }\end{array}$ & 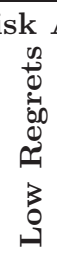 & $\underset{B}{Z}$ & $\frac{0}{2}$ \\
\hline $\begin{array}{l}\text { Develop strategic plan for sustainable transporta- } \\
\text { tion }\end{array}$ & & $\mathrm{X}$ & & $\mathrm{X}$ & & & \\
\hline $\begin{array}{l}\text { Develop national adaptation strategy and action } \\
\text { plan }\end{array}$ & & $\mathrm{X}$ & & & & $\mathrm{X}$ & \\
\hline $\begin{array}{l}\text { Create an adaptation framework that engages } \\
\text { stakeholders in the transportation sector }\end{array}$ & & $\mathrm{X}$ & & & $\mathrm{X}$ & & \\
\hline $\begin{array}{l}\text { Incorporate adaptation requirements in legislation } \\
\text { and regulatory norms }\end{array}$ & & $\mathrm{X}$ & & & $\mathrm{X}$ & & \\
\hline $\begin{array}{l}\text { Enhance standards and national/regional require- } \\
\text { ments }\end{array}$ & & $\mathrm{X}$ & & & & $\mathrm{X}$ & \\
\hline $\begin{array}{l}\text { Require climate risk and environmental assess- } \\
\text { ments for all new infrastructure }\end{array}$ & & $\mathrm{X}$ & & & & $\mathrm{X}$ & \\
\hline $\begin{array}{l}\text { Ensure funding for new infrastructure and exist- } \\
\text { ing infrastructure reinforcement }\end{array}$ & & & $\mathrm{X}$ & & & & $\mathrm{X}$ \\
\hline Coordinate future infrastructure plans & & $\mathrm{X}$ & & & & $\mathrm{X}$ & \\
\hline
\end{tabular}

\subsection{Infrastructure Design and Planning}

Smooth and effective operations of transportation systems rely heavily on infrastructures that are intended to last for many decades, possibly more than a century. Investments in the transportation infrastructure are usually costly. Therefore, an anticipatory approach is necessary for planning new infrastructure assets, and for existing infrastructure renovation, improvements and maintenance. Considering future climate trends now will help keep adaptation costs at manageable levels and avoid future unsustainable development paths for transportation systems.

Climate change adaptation must be considered at all relevant levels from network planning to project management. Concrete methodological guidance must be provided on how the integration can be implemented effectively [9]. Certain soft actions require relatively low investments. However, further mainstreaming of adaptation into transportation infrastructure investments can have substantial implications for infrastructure resilience and adaptation costs over the long term. In general, adaptation integrated in new and upgraded infrastructures comes at a lower cost than future integration.

Green actions include earthwork projects that combat landslides and green transportation networks that enhance energy efficiency, engage renewable en- 
Table 4. Infrastructure design and planning actions proposed in adaptation plans.

\begin{tabular}{|c|c|c|c|c|c|c|c|}
\hline Adaptation Action & 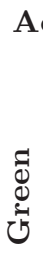 & ڤँّ & $\underset{\overparen{d}}{\vec{d}}$ & 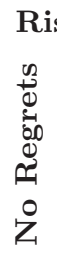 & 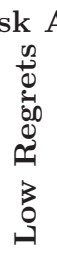 & 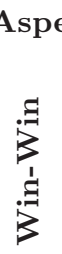 & 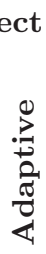 \\
\hline $\begin{array}{l}\text { Revise obsolete designs and infrastructure stan- } \\
\text { dards }\end{array}$ & & $\mathrm{X}$ & & $\mathrm{X}$ & & & \\
\hline $\begin{array}{l}\text { Create new standards and recommended practices } \\
\text { for infrastructure resilience }\end{array}$ & & $\mathrm{X}$ & & & & $\mathrm{X}$ & \\
\hline $\begin{array}{l}\text { Improve green design earthworks to combat land- } \\
\text { slides, subsidence, heaves and wind damage }\end{array}$ & $\mathrm{X}$ & & & & & $\mathrm{X}$ & \\
\hline $\begin{array}{l}\text { Perform regular civil engineering checks of infras- } \\
\text { tructure foundations and actions to combat ero- } \\
\text { sion }\end{array}$ & & & $\mathrm{X}$ & & & & $\mathrm{X}$ \\
\hline $\begin{array}{l}\text { Review piping and networks to identify vulnera- } \\
\text { bilities }\end{array}$ & & & $\mathrm{X}$ & & $\mathrm{X}$ & & \\
\hline $\begin{array}{l}\text { Strengthen drainage elements and improve storm } \\
\text { drain capacity }\end{array}$ & & & $\mathrm{X}$ & & & & $\mathrm{X}$ \\
\hline $\begin{array}{l}\text { Proactively inspect and maintain guidance for in- } \\
\text { frastructure assets }\end{array}$ & & & $\mathrm{X}$ & & & $\mathrm{X}$ & \\
\hline $\begin{array}{l}\text { Use design limits to explore if heating, cooling, } \\
\text { insulation or drying measures are required }\end{array}$ & & & $\mathrm{X}$ & & & & $\mathrm{X}$ \\
\hline $\begin{array}{l}\text { Design green transportation networks by improv- } \\
\text { ing energy efficiency, use renewable energy sources } \\
\text { and reduce the carbon footprint of transportation }\end{array}$ & $\mathrm{X}$ & & & & & $\mathrm{X}$ & \\
\hline
\end{tabular}

ergy sources and reduce carbon footprints. Table 4 presents the infrastructure design and planning actions categorized according to adaptation option type. The majority of the actions are classified as win-win - they reduce climate risk while providing other benefits and incremental actions for adaptive management.

\subsection{Redundancies in Transportation Modes}

Designing, building and using redundant infrastructure such as alternative roadways and rail links can enhance the resilience of transportation operations. Procuring and maintaining ready-to-use backup equipment and vehicles for emergencies and adding backup power generation capacity for critical facilities are important redundancy measures. Such strategies involve extra costs to establish and maintain redundancy that may not be needed during normal conditions. Nevertheless, redundancy strategies will become more important and 
Table 5. Redundancy planning actions proposed in adaptation plans.

\begin{tabular}{|c|c|c|c|c|c|}
\hline Adaptation Action & 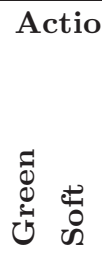 & 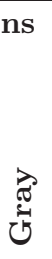 & 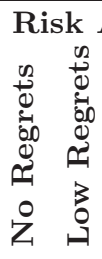 & $\underset{B}{\Xi}$ & 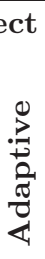 \\
\hline $\begin{array}{l}\text { Design and build redundant infrastructure in ar- } \\
\text { eas vulnerable to climate change }\end{array}$ & & $\mathrm{X}$ & & & $\mathrm{X}$ \\
\hline $\begin{array}{l}\text { Design and construct resilient vehicles for all } \\
\text { transportation modes }\end{array}$ & & $\mathrm{X}$ & & $\mathrm{X}$ & \\
\hline $\begin{array}{l}\text { Explore multi-modal opportunities (e.g., multi- } \\
\text { modal stations and flexible ticketing options) }\end{array}$ & & $\mathrm{X}$ & & $\mathrm{X}$ & \\
\hline $\begin{array}{l}\text { Build and maintain ready-to-use backup equip- } \\
\text { ment and vehicles for emergencies }\end{array}$ & & $\mathrm{X}$ & & & $\mathrm{X}$ \\
\hline $\begin{array}{l}\text { Add backup power generation capacity for critical } \\
\text { facilities }\end{array}$ & & $\mathrm{X}$ & & & $\mathrm{X}$ \\
\hline
\end{tabular}

more common as the number of extreme weather events and their magnitudes increase as a result of climate change.

Multi-modal transportation offers redundancies at multiple levels [9]. If different transportation modes are available, passengers would be able to select the best modes that meet their needs and switch from one mode to another as necessary. Smart and flexible ticketing enables passengers to switch operators and modes in the event of disruptions. Building and maintaining ready-touse backup equipment and vehicles for emergencies and adding backup power generation capacity for critical facilities also support adaptation efficiency.

Table 5 presents the redundancy planning actions categorized according to adaptation option type. As expected, redundancy actions correspond to gray measures because they require more funding and additional resources. The actions are categorized as win-win because redundancy options offer social benefits to transportation users and enhance adaptive management.

\subsection{Operational Contingency}

The transportation sector has traditionally implemented approaches to cope with the impacts of extreme weather events; these approaches also serve as valuable options for adapting to climate change. Preparation for risk situations is accomplished via contingency planning, business continuity planning and disaster recovery planning for extreme weather events. Emergency reporting, emergency equipment preparedness, surveillance and maintenance plans can enhance the integrity of critical facilities during adverse events. It is also important to position transportation assets away from vulnerable areas and 
Table 6. Operational contingency actions proposed in adaptation plans.

\begin{tabular}{ll}
\hline Adaptation Action & Actions \\
&
\end{tabular}

provide staff with personal protective equipment for use in operations during extreme events. Insurance schemes are also important because they can support key infrastructure funding and restoration in vulnerable areas.

Table 6 presents the operational contingency actions categorized according to adaptation option type. The actions are classified as either gray or soft. Green actions are missing because it is difficult to find green solutions that enhance operational contingencies for transportation assets. The listed options range from cost-effective measures to proportionate adaptive measures.

\subsection{Early Warning Systems}

Early warning systems enable transportation personnel to prepare for extreme weather events induced by climate change or climate variability. For example, Eurocontrol [5] has developed a natural hazards and weather resilience tool that provides information about the potential vulnerabilities of airports and en route sectors in Europe. Warning systems should leverage information and communications technologies to enhance transportation management. These include sensors and other devices that provide real-time information on traffic conditions such as temperature, vehicle speed, obstacles, deformations and other surface characteristics [11]. Information and communications tech- 
Table \%. Early warning systems proposed in adaptation plans.

\begin{tabular}{lll}
\hline Adaptation Action & Actions & Risk Aspect \\
& &
\end{tabular}

nologies enable this information to be accessed in real time by transportation infrastructure managers, service operators and users.

Vehicles and users are increasingly serving as data collectors, enabling infrastructure managers and operators to gain unprecedented real-time information about transportation systems. Handling these enormous flows of information requires advanced technologies that link vehicles to other vehicles and infrastructure, and process and disseminate the information. Transportation system operators and users in their vehicles can receive vital information about infrastructure conditions, infrastructure managers can obtain detailed descriptions of traffic conditions from users and disseminate the information. This greatly facilitates traffic management and enables passengers to adapt their plans and find alternative transportation options. It also improves the quality of transportation services and provides benefits to all the stakeholders, especially users and operators.

Table 7 presents the early warning systems categorized according to adaptation option type. Note that the early warning systems primarily correspond to gray and soft actions that require technological innovation and engineering support. They are also classified as win-win actions because they offer social and other benefits to stakeholders.

\subsection{Building Adaptive Capacity}

Global initiatives and transnational and national adaptation platforms are collecting relevant information pertaining to all stages of the policy process and making it easily accessible. For example, the European Climate Adaptation Platform (climate-adapt. eea. europa.eu) enables stakeholders to access and 
Table 8. Building adaptive capacity actions proposed in adaptation plans.

\begin{tabular}{lcl}
\hline Adaptation Action & Actions Risk Aspect \\
& &
\end{tabular}

share data and information on climate change, current and future vulnerabilities of regions and sectors, national and transnational adaptation strategies and actions, adaptation case studies and tools that enhance adaptation performance and planning.

Information collected on past weather events and their impacts is a valuable starting point for assessing vulnerabilities and developing strategies to adapt to climate change. Sharing knowledge about adaptation best practices and benchmarking implementation case studies help accelerate new initiatives. Additionally, education, training and public awareness efforts on climate change vulnerabilities and impacts also improve adaptation performance.

Table 8 presents the building adaptive capacity actions categorized according to adaptation option type. The (mainly) soft actions increase transportation resilience to climate change and are often cost-effective. However, this research has revealed that public platforms primarily provide information of a general nature; detailed technical and event data are scarce. These platforms should be upgraded and expanded to systematically collect and disseminate data about transportation disruption events at the national level.

\subsection{Comprehensive Collaboration}

Climate experts should make the various transportation stakeholders aware of the fact that climate-related topics cannot be addressed through traditional, deterministic methods and that alternative approaches for managing the risks brought upon by climate change should be explored. Transportation experts should collaborate to specify their climate forecasting needs in scientific terms, 
Table 9. Collaboration actions in adaptation plans.

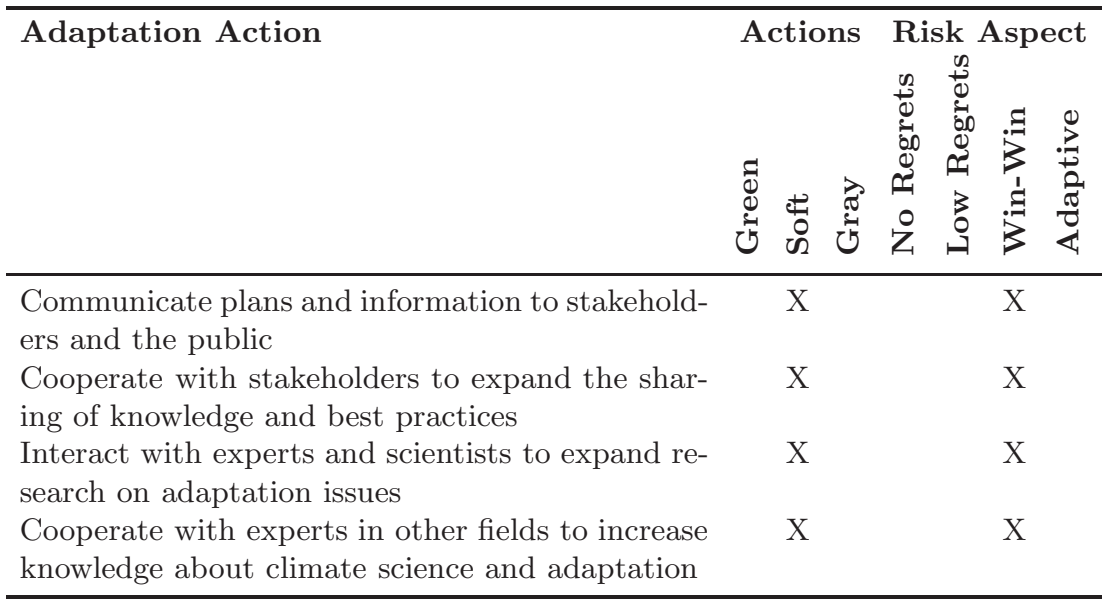

enabling meteorologists to better understand their needs and implement the appropriate solutions. Cooperative efforts by experts from diverse fields would enable transportation stakeholders to increase their management and decisionmaking flexibility.

Table 9 presents the collaboration actions categorized according to adaptation option type. The collaboration actions are primarily of the soft and win-win types. Cooperation among experts from different domains is a fruitful means to further adaptation efficiency and transportation system resilience.

\section{Conclusions}

Transportation systems are complex; they play a fundamental role in the economy and society and are characterized by long lifespans and high costs. These characteristics suggest the need for an adaptation approach with a longterm, systemic perspective that also prevents unsustainable development paths and maladaptation.

Several countries have begun to develop adaptation strategies and action plans that focus on the implementation of climate change adaptation measures in the critical infrastructure sectors, including transportation. The actions include information dissemination, capacity building, reviews of technical standards and the incorporation of new information and communications technologies. The engagement of all the principal stakeholders in the transportation sector is very important from the perspective of equity and efficiency. Therefore, regulatory authorities, policymakers and researchers should make strong efforts to engage transportation sector stakeholders in their research and information dissemination activities. 
Most climate change adaptation measures for the transportation infrastructure are soft actions (60\%). Gray actions are also quite popular $(35 \%)$ in existing adaptation plans. However, only $5 \%$ are green measures - this is a concern because the transportation sector is environmentally-invasive and consumes significant natural resources. It is imperative that climate change adaptation measures for the transportation infrastructure focus on improving energy efficiency and leveraging renewable energy. In general, low regret and win-win actions increase the resilience of transportation systems while providing advantages such as smooth operation, quality of service and efficiency.

Tools and measures for managing risks and impacts, such as early warning systems and contingency plans, can be used to enhance the resilience of the transportation infrastructure to climate change. Adaptation actions that focus on climate-proofing the transportation infrastructure should integrate adaptation requirements into the design of new and upgraded infrastructure - now as opposed to the future - in order to reduce costs over the long term. Another key adaptation action is to provide functionally-redundant options that build capacity and enable flexibility in the event of disasters and other interruptions.

Adaptation actions in the transportation sector should be continually monitored and analyzed. This would enable the principal stakeholders to improve the effectiveness and efficiency of climate change adaptation policy and its implementation. Stakeholders within and outside the transportation sector should also collaborate to ensure that the knowledge gained in other critical infrastructure sectors is leveraged to develop and implement innovative and effective solutions for adapting the transportation infrastructure to cope with the highly disruptive impacts of future climate change.

\section{References}

[1] S. Allen, V. Barros, I. Burton, D. Campbell-Lendrum, O. Cardona, S. Cutter, O. Dube, K. Ebi, C. Field, J. Handmer, P. Lal, A. Lavell, K. Mach, M. Mastrandrea, G. McBean, R. Mechler, T. Mitchell, N. Nicholls, K. O'Brien, T. Oki, M. Oppenheimer, M. Pelling, G. Plattner, R. Pulwarty, S. Seneviratne, T. Stocker, M. van Aalst, C. Vera and T. Wilbanks, Summary for policymakers, in Managing the Risks of Extreme Events and Disasters to Advance Climate Change Adaptation, Special Report of the Intergovernmental Panel on Climate Change, C. Field, V. Barros, T. Stocker, Q. Dahe, D. Dokken, K. Ebi, M. Mastrandrea, K. Mach, G. Plattner, S. Allen, M. Tignor and P. Midgley (Eds.), Cambridge University Press, Cambridge, United Kingdom, pp. 3-21, 2012.

[2] R. Bierbaum, A. Lee, J. Smith, M. Blair, L. Carter, F. Chapin, P. Fleming, S. Ruffo, S. McNeeley, M. Stults, L. Verduzco and E. Seyller, Adaptation, in Climate Change Impacts in the United States: The Third National Climate Assessment, J. Melillo, T. Richmond and G. Yohe (Eds.), U.S. Government Printing Office, Washington, DC, pp. 670-706, 2014. 
[3] V. Burkett, A. Suarez, M. Bindi, C. Conde, R. Mukerji, M. Prather, A. St. Clair and G. Yohe, 2014: Point of departure, in Climate Change 2014: Impacts, Adaptation and Vulnerability, Part A: Global and Sectoral Aspects, Contribution of Working Group II to the Fifth Assessment Report of the Intergovernmental Panel on Climate Change, C. Field, V. Barros, D. Dokken, K. Mach, M. Mastrandrea, T. Bilir, M. Chatterjee, K. Ebi, Y. Estrada, R. Genova, B. Girma, E. Kissel, A. Levy, S. MacCracken, P. Mastrandrea and L. White (Eds.), Cambridge University Press, Cambridge, United Kingdom, pp. 169-194, 2014.

[4] Committee on Climate Change and U.S. Transportation, Potential Impacts of Climate Change on U.S. Transportation, Transportation Research Board Special Report 290, Transportation Research Board, Washington, DC, 2008.

[5] Eurocontrol, Challenges of Growth 2013, Task 8: Climate Change Risk and Resilience, Brussels, Belgium 2013.

[6] European Commission, Roadmap to a Single European Transport Area - Towards a Competitive and Resource-Efficient Transport System, Directorate-General for Mobility and Transport, COM(2011) 144 Final, Brussels, Belgium, 2011.

[7] European Commission, An EU Strategy on Adaptation to Climate Change, Communication from the Commission to the European Parliament, the Council, the European Economic and Social Committee and the Committee of the Regions, $\operatorname{COM}(2013) 216$ Final, Brussels, Belgium, 2013.

[8] European Environment Agency, Adaptation in Europe - Addressing Risks and Opportunities from Climate Change in the Context of Socio-Economic Developments, EEA Report No. 3/2013, Copenhagen, Denmark, 2013.

[9] European Environment Agency, Adaptation of Transport to Climate Change in Europe - Challenges and Options Across Transport Modes and Stakeholders, EEA Report No. 8/2014, Copenhagen, Denmark, 2014.

[10] G. Forzieri, A. Bianchi, M. Marin Herrera, F. Batista e Silva, L. Feyen and C. Lavalle (Eds.), Resilience of Large Investments and Critical Infrastructures in Europe to Climate Change, Final Report for DG CLIMA, JRC Technical Report AA 071303/2012/630715//CLIMA.C.3 - JRC 329712012 NFP, European Commission, Brussels, Belgium, 2015.

[11] S. Grant-Muller and M. Usher, Intelligent transport systems: The propensity for environmental and economic benefits, Technological Forecasting and Social Change, vol. 82, pp. 149-166, 2014.

[12] P. Kotzanikolaou, M. Theocharidou and D. Gritzalis, Accessing n-order dependencies between critical infrastructures, International Journal of Critical Infrastructures, vol. 9(1-2), pp. 93-110, 2013.

[13] C. McLean, Y. Lee, S. Jain and C. Hutchings, Modeling and Simulation of Critical Infrastructure Systems for Homeland Security Applications, NISTIR 7785, National Institute of Standards and Technology, Gaithersburg, Maryland, 2011. 
[14] I. Niang-Diop and H. Bosch, Formulating an adaptation strategy, in Adaptation Policy Frameworks for Climate Change: Developing Strategies, Policies and Measures, B. Lim and E. Spanger-Siegfried (Eds.), Cambridge University Press, Cambridge, United Kingdom, pp. 183-204, 2004.

[15] Railway Safety and Standards Board, Tomorrow's Railway and Climate Change Adaptation (T1009), London, United Kingdom (www.rssb.co.uk/research-development-and-innovation/researchand-development/research-project-catalogue/t1009), 2016.

[16] G. Stergiopoulos, P. Kotzanikolaou, M. Theocharidou and D. Gritzalis, Risk mitigation strategies for critical infrastructures based on graph centrality analysis, International Journal of Critical Infrastructure Protection, vol. 10, pp. 34-44, 2015.

[17] G. Stergiopoulos, P. Kotzanikolaou, M. Theocharidou, G. Lykou and D. Gritzalis, Time-based critical infrastructure dependency analysis for largescale and cross-sectoral failures, International Journal of Critical Infrastructure Protection, vol. 12, pp. 46-60, 2016.

[18] G. Stergiopoulos, E. Vasilellis, G. Lykou, P. Kotzanikolaou and D. Gritzalis, Classification and comparison of critical infrastructure protection tools, in Critical Infrastructure Protection X, M. Rice and S. Shenoi (Eds.), Springer, Heidelberg, Germany, pp. 293-255, 2016.

[19] United Kingdom Climate Impacts Programme, Identifying Adaptation Options, Oxford, United Kingdom (www.ukcip.org.uk/wp-content/ PDFs/ID_Adapt_options.pdf), 2008.

[20] T. Wall and M. Meyer, Risk-Based Adaptation Frameworks for Climate Change Planning in the Transportation Sector: A Synthesis of Practice, Transportation Research Circular E-C181, Transportation Research Board, Washington, DC, 2013.

[21] World Resources Institute, The National Adaptive Capacity Framework: Key Institutional Functions for a Changing Climate Institute, Pilot Draft, Washington, DC (pdf.wri.org/working_papers/NAC_ framework_2009-12.pdf), 2009. 